\title{
The Construction of a Talent Training Mode Combining the Professional Teaching of Thai Language and the Practical Training of Overseas Learning In Higher Vocational Colleges \\ -- Take the Thai major of Yunnan college of foreign affairs and foreign languages as an example
}

\author{
Ya Liang, Yi He, Mengjia Hou and Ling Yang \\ Yunnan College of Foreign Affairs \& Foreign Languages, Yang Lin 651700
}

\begin{abstract}
Keywords: High vocational college; Thai language major; Professional construction; Teaching; Overseas internship training
\end{abstract}

\begin{abstract}
Applied Thai language species in Yunnan institute of foreign affairs in a foreign language professional support professional, since September 2013 start date of the first students, under the support and guidance of school policy, applied Thai obtained greater development. Articles from college application Thai professional development situation and present situation analysis, Thai professional course construction, the construction of overseas practice, existing problems and application of Thai professional talent training mode reform development path for our application Thai professional training the combination of teaching and study abroad discusses the construction of personnel training mode, is expected to better adapt to development strategy of "area" in Yunnan province, the implementation of the college development policy and strategy, better realize the goal of talent training.

This paper is funded by the Yunnan provincial education department's scientific research project.A probe into the talent training mode of combining the professional teaching of Thai language with the practical training of overseas learning in higher vocational colleges. Subject no. 2017ZDX289
\end{abstract}

In recent years, as the bridgehead construction in Yunnan province and the development of the strategy of "area", there are quite a few scholars put research Angle of view to the specialty construction in colleges and universities, the combination of both the teaching and study abroad training personnel training mode construction, etc. Chen Shougen (2011) made an analysis on the content and methods of professional construction in higher vocational colleges. Ma jun and Xie Yongqi (2009) also elaborated the planning of professional construction in higher vocational colleges. Lu Jingquan (2014) also conducted relevant studies on the construction practice of higher vocational education major. Huang Haiwu (2011) studied and discussed the construction of a professional internship base. Small language professional construction, Wei Jinling (2012), under the background of China - asean, small language tour guide personnel training mode in colleges and universities in Guang $\mathrm{Xi}$ were studied, analyzed the problems existing in the current Guangxi colleges and universities cultivate small language guide, think of colleges and universities and education administrative department attaches great importance to the small language tour guide personnel training and put forward under the background of China-Asean, Guangxi university small language guide the construction of personnel training mode; Ian Liming (2012), 2010-2011 in guangxi university for Thai students, for example, in the Thai Chinese interns cross-cultural adaptation and the countermeasure has carried on the exploration, for both the teaching and study abroad training personnel training mode of combining construction provides guidance;Huang Ming and Deng Lina (2016), taking the Thai major of Chengdu university as the research object, studied the construction of the "Thai, English and Chinese" trilingual talent training model. At present, from a large number of literatures, there are many researches on the construction and planning of college majors, which means that professional construction plays a particularly important role in teaching. However, there are few and scattered researches on the construction of talent training model combining college teaching with overseas learning and practical training. This paper will take Yunnan college of foreign affairs as an example to explore the construction of talent training mode 
combining the teaching of Thai language major and the practical training of overseas study.

\section{Analysis on the Development and Current Situation of Applied Thai Language in our Hospital}

Yunnan institute of foreign affairs in a foreign language professional, approved by the people's government of Yunnan province, the People's Republic of China agree to put on record, after review into the state's unified planned enrollment, since was established in 2012, the school has always been to "foreign affairs, the world language" as my school characteristic theme culture, adhere to the "education, education first" the principle, application in September 2013 began to recruit Thai students, under the leadership of the school of policy support and, applied Thai obtained greater development.

(1) Analysis of changes in the number of people majoring in applied Thai

In September 2013, our school opened the first professional class of applying Thai language, which enrolled 13 three-year college students and 9 five-year college students. In 2014, 12 three-year college students and 16 five-year college students were enrolled in the application of Thai Language. In 2015, 18 three-year college students and 18 five-year college students were enrolled in the applied Thai language major, which increased significantly compared with the previous two years. Is our Thai professional number 2016 A year more, the five-year college, for more than 40 people, in order to achieve the teaching purpose, apply the five-year junior level 2016 Thai class teaching is divided into two groups A and B, A three-year students for 20 people; In 2017, because the overall enrollment of the school is small, the number of students majoring in Thai is small, including 15 three-year college students and 21 five-year college students. As shown in Fig. 1-1:

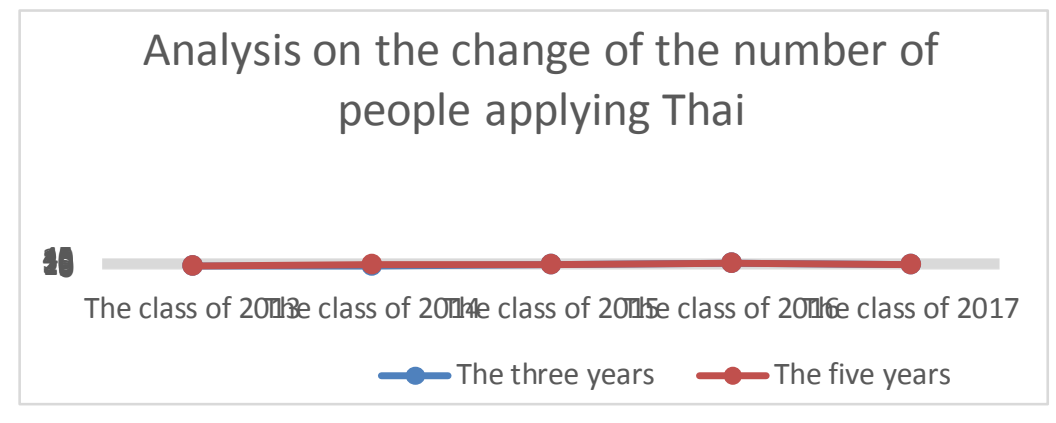

Figure 1-1. Finite

(2) Analysis of the situation of the cet-4 in the applied Thai language major

In June 2016 for the first time in our school take Thai professional level 4 test, our Thai professional three-year college students in grade 2013 and 2014, a total of 15 people to take an examination, by the number is only 1 person, pass rate of $6.67 \%$; In June 2017, a total of 29 students from grade 2013 and grade 2014 three-year colleges and universities and grade 2013 five-year colleges and universities of our university took the exam, 8 of them passed the exam, with a passing rate of $27.79 \%$.

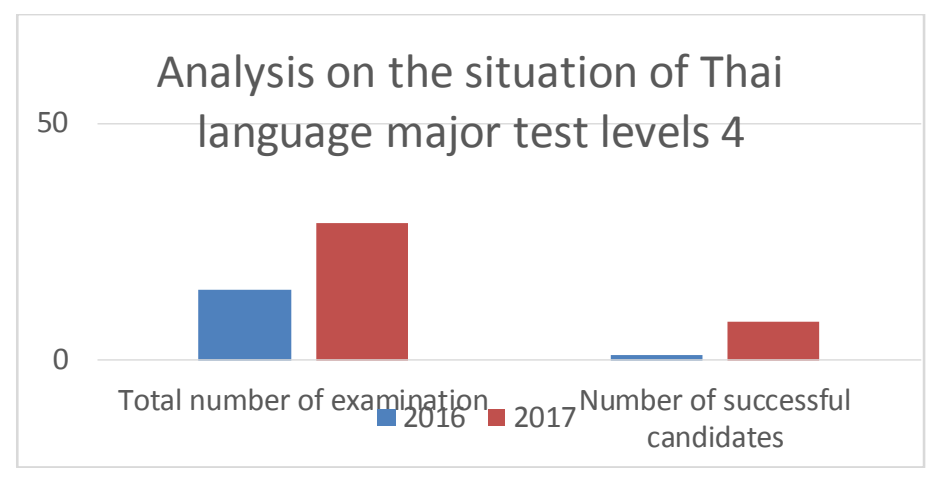

Figure 2-2. Finite 
As shown in Fig. 2-2:

The passing rate has been improved to a certain extent compared with the previous year, which is mainly attributed to the following reasons:(2) more opportunities for international exchanges and cooperation, and students' own language level has been improved;(3) the Thai language teaching and research office organizes simulated examinations for students' guidance.

According to the institute of policy and development ideas, combining colleges has to carry out and practice the cooperation and exchange of Thailand before project implementation as a result, it can be seen in our application of Thai professional foreign exchange has good prospects for development.

\section{Curriculum Construction of Thai Language Major in our School}

College to cultivate high-quality talents in the field of technical skills as the goal, adhere to the service for the purpose, with Khalid ents as the fundamental, to the employment as the guidance, "education, moral education first", in the "foreign affairs all over the world, the world language" of the university on the theme of culture, to absorb in recent years, higher vocational education in the education idea, training mode, teaching content and course system, teaching method and means of reform efforts, combined with the present situation of the education teaching reform, to implement work-integrated learning, cooperation between colleges and reform talents training mode, build a working process oriented curriculum system, the revision of the professional industry and professional talent training scheme distinct characteristics.

(1) curriculum system

1. Compulsory course: public basic course, professional basic course, professional core course, professional comprehensive practice course;

2. Elective courses: public elective courses, professional elective courses;

3. Evidence collection, social practice, skill competition, professional qualification certification, comprehensive quality development.

(2) curriculum

1. 5-year specialized courses in applied Thai language and textbook information

\begin{tabular}{|c|c|c|}
\hline year & Course name & Name of the teaching material \\
\hline \multirow{17}{*}{$\begin{array}{l}\text { The } \\
\text { five-year }\end{array}$} & Basic Thai listening and speaking (1) & Spoken Thai tutorial \\
\hline & Basic Thai listening and speaking (3) & Spoken Thai tutorial \\
\hline & Intensive reading of basic Thai language (1) & Basic Thai (1) \\
\hline & Intensive reading of basic Thai language (3) & Basic Thai (2), basic Thai (3) \\
\hline & Thai intermediate advanced (1) & Basic Thai 3 \\
\hline & Intermediate/advanced Thai (2) & Basic Thai 4 \\
\hline & Thai intermediate advanced (3) & $\begin{array}{l}\text { Thai language course (volume } 3 \text { ) (revised } \\
\text { edition) }\end{array}$ \\
\hline & Spoken Thai (1) & Spoken Thai tutorial \\
\hline & Spoken Thai (2) & Spoken Thai tutorial \\
\hline & Thai reading (1) & University Thai reading course \\
\hline & Thai reading (2) & University Thai reading course \\
\hline & Thai writing (1) & Thai writing course \\
\hline & Thai writing (2) & Thai writing course \\
\hline & Chinese-Thai translation (1) & Practical Chinese-Thai translation course \\
\hline & Chinese-Thai translation (2) & Practical Chinese-Thai translation course \\
\hline & Thai grammar (1) & Thai grammar new edition \\
\hline & Thai society and culture & Thai folk customs and culture \\
\hline
\end{tabular}

Figure 3-1. Finite 
As shown in Fig. 3-1, five-year college application for our Thai professional course setting and teaching information, respectively, on the basis of Thai heard, basic Thai, intensive reading, Thai senior, Thai, Thai, speaking, reading, and Thai, Thai Chinese translation, Thai, grammar and writing Thai society and culture. Chose for the five-year characteristics and learning ability of students to study the teaching material, the five-year college application of Thai students studying by these courses, in Thai, listening, speaking, reading, writing, translating and so on to get a good training skills, to master the Thai language, politics, economy, trade, social and cultural aspects of the basic theory and basic knowledge, and obtain corresponding credits.

2. Three-year specialized courses in applied Thai language and textbook information

\begin{tabular}{|c|c|c|}
\hline year & Course name & Name of the teaching material \\
\hline \multirow{28}{*}{$\begin{array}{c}\text { The } \\
\text { three-yea } \\
\text { rs }\end{array}$} & Integrated Thai (1) & Basic Thai (1) \\
\hline & Integrated Thai (2) & Basic Thai (1) \\
\hline & Integrated Thai (3) & Basic Thai (2) \\
\hline & Integrated Thai (4) & Basic Thai 3 \\
\hline & Thai listening and speaking (1) & Spoken Thai tutorial \\
\hline & Thai listening (1) & University Thai listening course (part 1) \\
\hline & Thai listening (2) & University Thai listening course (part 1) \\
\hline & Thai listening (3) & University Thai listening course (part 1) \\
\hline & Thai listening (4) & University Thai listening course (part 2) \\
\hline & Spoken Thai (1) & Spoken Thai tutorial \\
\hline & Spoken Thai (2) & Spoken Thai tutorial \\
\hline & Spoken Thai (3) & Spoken Thai tutorial \\
\hline & Spoken Thai (4) & Spoken Thai tutorial \\
\hline & Thai reading (1) & University Thai reading course \\
\hline & Thai reading (2) & University Thai reading course \\
\hline & Thai reading (3) & University Thai reading course \\
\hline & Thai reading (4) & University Thai reading course \\
\hline & Thai writing (1) & Thai writing course \\
\hline & Thai writing (2) & Thai writing course \\
\hline & Thai writing (3) & Thai writing course \\
\hline & Thai writing (4) & Thai writing course \\
\hline & Chinese-Thai translation (1) & Practical Chinese-Thai translation course \\
\hline & Chinese-Thai translation (2) & Practical Chinese-Thai translation course \\
\hline & Chinese-Thai translation (3) & Practical Chinese-Thai translation course \\
\hline & Thai grammar (1) & Thai grammar new edition \\
\hline & Thai grammar (2) & University Thai language integrated course 3 \\
\hline & Chinese and southeast Asian cultures & Introduction to southeast Asia \\
\hline & Tourism Thai & Tourist Thai \\
\hline
\end{tabular}

Figure 3-2. Finite

Shown in Fig. 3-2, for our school's three-year college application Thai professional course setting and teaching information, respectively, the comprehensive Thai, Thai heard, Thai, listening comprehension, Thai, Thai, speaking, reading, and Thai writing, Thai, Thai, grammar, the mutual translation chinese culture of China and southeast Asia and travel Thai. Chose for the five-year characteristics and learning ability of students to study the teaching material, a three-year college application of Thai students through learning these courses, so as to master the Thai language, politics, economy, trade, social and cultural aspects of the basic theory and basic knowledge, 
understand the history and present situation of international relations, Buddhism, education, economy and trade, or tourism status, and obtain corresponding credits.

At present the hospital in addition to the application of Thai professional course teaching in foreign language institute of aviation, also in the aviation professional opened the course "the civil aviation Thai" in nursing college courses in the journal of nursing Thai, aviation professional and all nursing college students are expected to learn Thai, in addition, also in hospital scale small language elective courses in the "Thai", take the student covered the professional college.

(3)Our school overseas study training construction

The rise of China, southwest China took off, as a bridgehead for South Asia, southeast Asia development in Yunnan province, Yunnan as "area" international development strategy target one of the provinces, radiation throughout the South Asia, southeast Asia and Thailand, Laos and Vietnam border, is China's border with asean countries most provinces. The economic take-off and the development of foreign affairs will certainly bring the demand for foreign affairs talents an inevitable opportunity. According to the development strategy goal of China, our university actively constructs a talent training mode combining professional teaching with overseas learning and practical training to cultivate applied talents.

(I) Relevant cooperative institutions signed by our university and Thailand

Since it was founded in 2014 in our school since the international exchange center, takes the foreign world, language education aim of the world, and in several institutes of higher learning in Thailand and Vietnam, administrative institutions signed a cooperation study and project practice training bases.

1. Universities and institutions in cooperation with Thailand

Kanchanaburi universities of Thailand, Chiang Mai university, Emory university, Royal university, BoRen university and University of Siam, Palmer house vocational and technical college, Uttaradit royal university, Su Jinna infants aged care training school, John rambo larry's college of nursing, Palmer house Wallace Tang Xiaoxue, Palmer house Chinese language training center, Rahul nana boutique hotel, etc.

2. Our school establishes cooperation projects with Thailand

Language and culture training base, internship training base, nursing practice training base, ielts overseas training center, hotel management professional training base, and upgrading of the educational background.

(ii) Implementation of the cooperation training base between Thai language major students and Thailand

The forms of sino-Thai exchange and cooperation projects of our college include: short-term (21 days) study Tours, short-term exchange study, one-month exchange study, four-month exchange study, and academic improvement (upgrading).According to statistics, 41 students were sent to participate in the four-month exchange study in 2015, 15 in 2016 and 14 in Thailand. In 2017, 33 people will be sent for short-term exchange and study, and 4 people will be promoted in academic degree. Sixteen students from Thailand will be admitted in 2018. The overall trend of steady development has been stable and good results have been achieved.

1、 Our students go to Thailand to participate in the courses and activities of language and culture cooperation

(1) the courses offered are mainly specialized basic courses

Thai spoken language, Thai listening, Thai reading, Thai writing, Thai culture.

(2) Thai cultural exchange activities

Thai festivals, Thai food, wreath making, pastry making, costume display, dancing, Thai boxing, etc.

(3) visit Thailand's historic sites

2. Courses and activities for visiting students from Thailand

(1) offering courses that combine Chinese learning with Chinese cultural communication

Chinese folklore (paper-cut tea art), martial arts, Musical Instruments (hulusi), traditional Chinese massage, calligraphy, civil aviation Chinese 
(2) visit kunming historic sites

\section{Existing Problems}

According to the analysis of relevant materials related to the practical training of overseas learning practice in Thailand, the following problems exist in the construction of the training mode of Thai language professionals in our school:

Number 1. The signed cooperation with Thailand colleges, but the specific implementation related cooperation between schools, mainly and Chiang mai university, Kanchanaburi royal university professional study is given priority to, other students to participate in overseas exchange is less;

2. Students have a relatively short learning time and a relatively simple form in Thailand's overseas internship and training base;

3. The signed school-enterprise cooperation has not developed sufficiently and the platform constructed is relatively small.

\section{The Path of Reform and Development of Talent Training Model}

1. Make specific plans for studying in Thailand according to the curriculum setting and training objectives of Thai majors, and improve the exchange and cooperation mechanism between the two sides;

2. Select fixed cooperation schools in Thailand according to the training objectives and the actual specialty to ensure the quality and form a complete, fixed and high-quality cooperation model;

3. Actively build a platform for exchanging teachers and students;

4. Improve the system of professional teaching and overseas learning courses, strengthen systematic learning and guarantee the teaching quality;

5. Expand communication channels and build more communication platforms so that students who speak Thai as a second foreign language can participate in more exchanges and learning between China and Thailand;

6. Strengthen the construction of the school-enterprise cooperation model between China and Thailand, expand the single overseas study to overseas practice and training, and achieve the real international talent training.

Application in Yunnan institute of foreign affairs in a foreign language professional articles on the Thai professional training objectives and international exchanges and cooperation in the actual development situation of the project, the institute since applied Thai professional development present situation and development prospects, curriculum system and course construction, in the construction of overseas practice of college assignments and students receive detail, college and Thailand cooperation practice base of school courses and activities as well as the existing problems and solving methods are expounded and discussed, hoping to provide reference for other professional conducting external exchanges.

\section{Reference}

[1] QingShuo Yao Lei. The association of south-east Asian nations (asean) - the high-end of the north opportunities under applicable tourism talents cultivation research - to wuzhou institute of tourism management professional (undergraduate), for example [J]. Journal of coastal enterprises with science and technology, 2011 (6).

[2] Wei Qing, Wang Hui, Yu Na. Analysis on the current situation of the demand for foreign-related tourist guides in Guang $\mathrm{Xi}$ and countermeasures for training them [J]. Journal of Guang Xi university of finance and economics, 2010 (01).

[3] Ma Jun, Xie Yongqi. Brief discussion on professional construction planning in higher vocational colleges [J]. Research on education in higher vocational schools,2009(01).

[4] Zhou Wang. Practical exploration on the talent cultivation model of "integration of transnational 
engineering and science" [J]. Education management,2008(27).

[5] Li Xiaoming. Study on intercultural adaptation of Chinese interns in Thailand and countermeasures -- a case study of Guang Xi university students in Thailand from 2010 to 2011 [D]. Guangxi university,2012.

[6] Chen Shougen. Analysis on the content and methods of professional construction in higher vocational colleges [J]. Occupational technology education,2011(11).

[7] Huang Haiwu. Research and discussion on the construction of professional internship base [J]. Guangxi education, 2011 (8).

[8] Huang Ming, Deng Lina. Exploration and practice of the "taiying and Chinese" trilingual talent cultivation model -- a case study of the Thai major of ChengDu university [J]. Advanced education-curriculum and teaching,2016(08).

[9] Wei Jinling. Research on the training model of small-language tourist guides in GuangXi universities under the background of China-Asean [D]. Guangxi university,2012.

[10] Lv Jingquan. Research on the construction practice of higher vocational education specialty [D]. Tianjin university,2014.

[11] Hai-tao Jiang, Wang Yao, Li Peng. The implementation of the "double certificates" system, innovative talent training mode - in tourism and hotel management of the implementation of the "double certificates" system, for example [J]. High technology and new technology enterprise in China, 2007 (12).

[12] Liu Enlin. Innovation of intercollegiate cooperation and talent cultivation model in Chinese universities [D]. Shandong university, 2010. 